IRA-International Journal of Applied Sciences ISSN 2455-4499; Vol.08, Issue 01 (July 2017)

Pg. no. 1-17

Institute of Research Advances

https://research-advances.org/index.php/IRAJAS

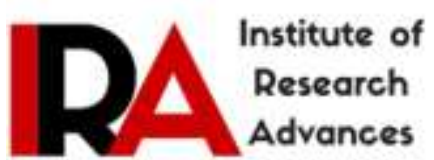

\title{
Generation of a Chimeric Antibody against a Synthetic Peptide Derived From IL-23p19 with Potential Therapeutic Application
}

\author{
Pérez-Etcheverry Diana and Lorenzo-Ferreiro Carmen \\ Laboratorio de Biotecnología del Instituto Polo Tecnológico de Pando - Facultad de Química, \\ Universidad de la República. Canelones, Uruguay.
}

Type of Review: Peer Reviewed.

DOI: http://dx.doi.org/10.21013/jas.v8.n1.p1

\section{How to cite this paper:}

Diana, P., Carmen, L. (2017). Generation of a Chimeric Antibody against a Synthetic Peptide Derived From IL-23p19 with Potential Therapeutic Application. IRA International Journal of Applied Sciences (ISSN 24554499), 8(1), 1-17. doi: http://dx.doi.org/10.21013/jas.v8.n1.p1

(C) Institute of Research Advances.

\section{(cc) Br-No}

This work is licensed under a Creative Commons Attribution-Non Commercial 4.0 International License subject to proper citation to the publication source of the work.

Disclaimer: The scholarly papers as reviewed and published by the Institute of Research Advances (IRA) are the views and opinions of their respective authors and are not the views or opinions of the IRA. The IRA disclaims of any harm or loss caused due to the published content to any party.

Institute of Research Advances is an institutional publisher member of Publishers Inter Linking Association Inc. (PILA-CrossRef), USA. The institute is an institutional signatory to the Budapest Open Access Initiative, Hungary advocating the open access of scientific and scholarly knowledge. The Institute is a registered content provider under Open Access Initiative Protocol for Metadata Harvesting (OAI-PMH).

The journal is indexed \& included in CAS Source Index of Chemical Abstracts Service of American Chemical Society (USA), WorldCat Discovery Service (USA), CrossRef Metadata Search (USA), WorldCat (USA), OCLC (USA), Open J-Gate (India), EZB (Germany) Scilit (Switzerland), Airiti (China), Bielefeld Academic Search Engine (BASE) of Bielefeld University, Germany, PKP Index of Simon Fraser University, Canada. 


\begin{abstract}
Aim: To construct an express a mouse-human chimeric antibody against IL-23p19 using a synthetic peptide as immunogen. Methods: Immunization of mice with a synthetic peptide derived from the IL-23p19 sequence and generation of hybridoma secreting specific antibodies. The chimeric antibody was created using two eukaryotic plasmid constructions; one of them carrying the light mouse-human chain and the other the heavy mouse-human chain. CHO-Kl cells were cotransfected with both plasmids and stable transfectants were grown in selective culture medium. Results: A chimeric version of anti-IL-23p19 was successfully constructed and expressed in eukaryotic cells. The expressed chimeric antibody showed specific recognition not only of the peptide used as immunogen but also the subunit p19 and the complete interleukin Il-23. Conclusion: A Chimeric antibody that was developed against a synthetic peptide, which is able to recognize the parent protein IL23 biologically active, could be developed into a targeted therapy in diseases with chronic inflammation.
\end{abstract}

Keywords: IL-23, chimeric antibody, peptide

\title{
Introduction
}

Targeted therapy using specific monoclonal antibodies $(\mathrm{mAb})$ offers an alternative for the treatment of diverse chronic diseases such as autoimmune disease or cancer[1]. Initial developments used mouse monoclonal antibodies, nevertheless with very poor clinical achievement, undesired anti-mouse response; low half-lives in humans and lack of efficacy of the Fc functions were the main drawbacks[2-4]. Construction of human-mouse chimeric antibody, human reshaped antibody and humanization via epítope guided selection by phage display are the main approaches available to overcome those difficulties [5-9]. Chimeric antibodies keep the parent murine variable regions consequently the binding specificity and affinity. Though preserve more mouse sequence than other methods, they have the advantage of easier to construct and can be easily in vitro reshaped[10]. In this work we successfully generate a chimeric antibody that recognizes the p19 subunit of the interleukin IL-23 after immunization of mice with a synthetic peptide derived from the protein sequence, as immunogenic epitope. IL-23 is a member of the IL-12 family, structurally consist in a heterodimer of two subunits, a smaller subunit named p19 and a larger one named $\mathrm{p} 40$, which is counterpart of the p40 of the IL-12[11]. Also IL-23 and IL-12 both are ligands for the IL-12 receptor beta subunit (IL-12R $\beta 1)[12]$. Physiologically, IL-23 is produced by antigen presenting cells (APC) and promotes the expansion and survival of Th17 cells, but has no role in the differentiation of the lineage. In pathologic situation IL23 is strongly associated to autoimmune diseases and chronic inflammation [13-16], in particular its involvement in Psoriasis [17], Miastenia Gravis [18], Rheumatoid Arthritis[19] and inflammatory bowel disease [20-22] has been described. Currently, the study of the combination IL-23, IL-12/Th17 as a therapeutic target is of great interest as demonstrated by the various antibodies recently subjected to clinical studies[14]. Hueber et al. showed that using antagonist of the path IL-17A / IL-17AR provided good results in psoriasis but in the contrary resulted in exacerbation in Chron disease [23]. Experiment in mice showed that IL-17A and IL-22 are produced in the gut constitutively, in a independent manner of IL-23, the authors propose that those basal levels could be essential for keeping normal function of the epithelium and high levels induced by IL-23 in presence of other pro inflammatory cytokines could develop pathogenic situation with tissue damage [24]. Suppression of IL-23 by means anti IL23 p19 could partially inhibit IL-17A and reduce inflammation, whereas an anti-IL-17 therapy would neutralize all IL-17A including protective ones[14]. We selected IL-23 based on its therapeutic value and developed a specific chimeric antibody anti-IL-23p19 by means of hybridoma technique. Immunization of mice was done with a synthetic peptide representing an exposed epítope of p19. Once having a hybridoma secreting reactive antibodies (mab-3D7); RNA was extracted from hybrid cells and mouse immunoglobulin variable heavy and light chain were amplified. The chimeric chains were constructed using two eukaryotic vectors, one of them containing the mousehuman light chain and the other the mouse-human heavy immunoglobulin chain. CHO-K1 cells were transfected with both plasmids simultaneously and we selected co-transfectants by antibiotic resistance. Stable transfectants expressing the chimeric antibody (ch-3D7) with desired specificity was obtained. We proved that the chimeric antibody originally generated against a synthetic peptide recognizes the protein in its native form. 


\section{Materials and Methods}

\section{Antigens}

The peptide KEEGDEETTNDVP was obtained by Fmoc solid-phase synthesis (ResPep Intravis AG, Bioanalytical Instrument). The sequence was designed following a computational study of hydrophilic domains of the p19 amino acid sequence using several applications of the ExPASy Proteomics Server (http://web.expasy.org/protscale)[25]. The first arginine residue constitutes the positively charged tag used to favor an oriented binding.

Bovine serum albumin (BSA) (Sigma USA) and Keyhole limpet hemocyanin (KLH) (Sigma, USA) were used as protein carriers for immunization. Protein-peptide conjugates were prepared as follows: firstly, the peptide, the BSA and the KLH were separately derivatized with succinimidyl 3-(2-pyridyldithiopropionate (SPDP) (Thermo Scientific, USA) in order to generate active intermediates. Briefly, $2 \mathrm{mg}$ of each biomolecule was dissolved in $1 \mathrm{ml}$ of Phosphate Buffer Saline (PBS), 1mM EDTA (Sigma, USA); then 20mM SPDP dissolved in DMSO (Sigma, USA), (mol to mol ratio) was added to each reaction incubating $1 \mathrm{~h}$ at room temperature. Finally, protein reaction solutions were dialyzed against 0.1M Acetic acid (Dorwil, Argentine) $100 \mathrm{mM} \mathrm{NaCl}$ (Dorwil, Argentine) $\mathrm{pH} 4.5 \mathrm{and} 50 \mathrm{mM}$ DTT (Sigma, USA) in $0.1 \mathrm{M}$ Acetic acid, $100 \mathrm{mM} \mathrm{NaCl} \mathrm{pH} 4.5$ was then added to each tube with subsequent incubation 30min at room temperature. Excess DTT was removed using a PD-10 Desalting Column (GE Healthcare, USA) following manufacturer's instructions. BSA-peptide and KLH-peptide conjugates were obtained by mixing $1 \mathrm{ml}$ of activated peptide solution with $1 \mathrm{ml}$ of each activated protein solution. Incubation time was $18 \mathrm{~h}$ at room temperature.

To prepare peptide-peptide conjugate, $2 \mathrm{mg}$ of peptide were dissolved in 500 $\mu 10.1 \mathrm{M}$ MES buffer (Sigma, USA)

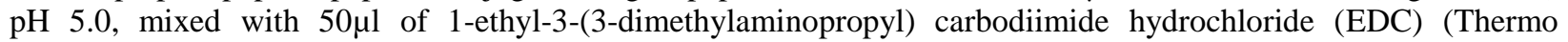
Scientific, USA) in ultrapure water, and incubated $2 \mathrm{~h}$ at room temperature.

To measure the specific antibody response against the peptide by ELISA, a conjugated to the synthetic maleic anhydride-alt-methyl vinyl ether copolymer (P(MAMVE)) (Sigma, USA) was prepared. $100 \mu 10.1 \mathrm{M} \mathrm{KH}_{2} \mathrm{PO}_{4} \mathrm{pH}$ 6.8 containing $18 \mu \mathrm{g}$ of peptide and $5 \mu \mathrm{g}$ of $\mathrm{P}(\mathrm{MAMVE})$ in DMSO were mixed during $3 \mathrm{~h}$ at $37^{\circ} \mathrm{C}$ with agitation[26]. All conjugates were analyzed by Size Exclusion Chromatography using BIOSEP-SEC-S3000 (Phenomenex, USA) $0.5 \mathrm{ml} / \mathrm{min}$ (data not shown).

Two recombinant forms of p19 (rHis-p19 and rGST-p19) previously generated and purified in our lab were used. Recombinant human IL-23 biologically active was purchased at eBioscience (San Diego, USA).

\section{$m A b s$}

Mab-3D7 was obtained as follows; three mice were primed subcutaneously with $20 \mu \mathrm{g}$ of BSA-peptide conjugate in Alumina adjuvant (Sigma, USA), and boosted two times once a week using $20 \mu \mathrm{g}$ peptide-peptide conjugate and $20 \mu \mathrm{g}$ KLH-peptide conjugate respectively in Freund's incomplete adjuvant (Sigma, USA). Three days after the last booster the mouse with the highest antibodies titer against the P(MAMVE)-peptide conjugate was killed and the splenocytes fused with SP2/0-Ag14 cells (ATCC, USA), basically as described in[27]. The protocol used for immunization was accepted by the corresponding authorities (Comisión Honoraria de Experimentación Animal (Consejo de Facultad de Química, UDELAR; Exp. No 101900-000502-11)

\section{Isolation of the cDNA encoding $\mu$ and $\boldsymbol{k}$ murine immunoglobulin variable regions}

Variable $\mu(\mathrm{MV} \mu)$ and variable $\kappa(\mathrm{MV \kappa})$ murine regions were obtained from RNA of 3D7 hybridoma cells, reactive against the peptide.

The 5'RACE System for Rapid Amplification of cDNA Ends (Invitrogen, Life Tecnchnologies) was used in combination with a set of four specific antisense primers designed from murine $\mu$ and $\kappa$ constant regions coding sequences reported at Genbank (NIH, Bethesda, MD, USA). Available sequences were aligned using Multiple Sequence Alignment ClustalW (http://embnet.vital-it.ch/software/ClustalW.html/) (EMBL-EBI, Wellcome Genome Campus, Hinxton, Cambridgeshire, UK) and oligonucleotides were analyzed using Oligo Analyzer - 1.5 
(GeneLink ${ }^{\mathrm{TM}}$ ) (Figure 4). Briefly, total RNA was isolated from 3D7 hibridoma cells using Trizol® Reagent (Sigma, USA) according to the manufacturer's instructions and antisense oligonucelotides MIgMR (5'ACAGGGGGCTCTCGCAGGA-3') and MCkR (5'-AGAAGCACACGACTGAGGC-3') were used to reversetranscribe $\mu$ and $\kappa$ variable regions (MV $\mu$ and MV $\kappa$ respectively). Then cDNAs were tailed as described by the kit manufacturer and subsequently amplified by PCR at $\mathrm{Tm}=55^{\circ} \mathrm{C}$ using Pfu Polymerase (Invitrogen, USA) with a second corresponding antisense primer (MIgMR_N:5'-CATTTGGGAAGGACTGACTCTC-3' for MV $\mu$ and MCKR_N: 5'-ACTGGATGGTGGGAAGATG-3' for MVк) and the abridged anchor primer provided by the kit, essentially as described by the manufacturer. The PCR products thus obtained were cloned into the Topo TA Cloning Vector (Invitrogen, USA) following standard procedures and sequenced at Macrogen, Inc., Korea. The results from sequencing were submitted to informatics analysis by Translate Tool (http://www.expasy.org/translate), SignalP 4.1 Server[28] (http://www.cbs.dtu.dk/services/SignalP/) and IMGT/V-QUEST [29] .

\section{Construction of chimerical DNA fragments encoding Heavy and Light Immunoglobulin chains by overlap extension PCR}

Heavy and light chimerical immunoglobulin's encoding DNA were obtained by overlap extension PCR[30] from cDNAs encoding fragments of murine MVк and MV $\mu$ mentioned above and human encoding constant $\kappa$ and $\operatorname{IgG} 1 \gamma$ fragments, previously cloned and kindly provided by Dr. Molina-Sampayo (ICBM, Facultad de Medicina Universidad de Chile)[31]. Briefly, murine and human encoding fragments were amplified by PCR (Pfu Polymerase) using the primers listed in Table 1 and Figure 6.

The PCR products obtained were analyzed and isolated from 1.5\% agarose gels according to standard techniques and then combined into two sets of overlap extension PCR reactions. The chimerical $\mu-\gamma$ fragment was obtained by combining equimolar amounts of MV $\mu$ and constant IgG1 $\gamma$ fragments (final mass of 3ng of DNA) in a $25 \mu 1$ PCR mix, using VmuMF and Cg1HR pair of primers, HotStart Polymerase (Bioline, UK) and a $\mathrm{Tm}=53^{\circ} \mathrm{C}$. Likewise, the

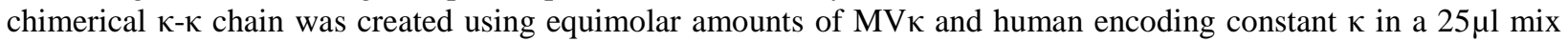

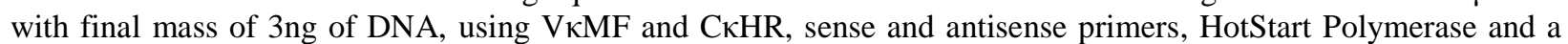
$\mathrm{Tm}=51^{\circ} \mathrm{C}$.

The PCR products were analyzed and purified form gel, and digested with NheI and BamHI (Fermentas, USA). The $\mu-\gamma$ fragment was cloned between the corresponding sites in the pcDNA 3.1 (-) vector (Invitrogen, USA) to construct the pcDNA $3.1(-) / \mu-\gamma$ plasmid and the chimerical $\kappa-\kappa$ between the corresponding sites in the pSecTag2B vector (Invitrogen, USA) to generate the $\mathrm{pSecTag} 2 \mathrm{~B} / \kappa-\kappa$ vector.

\section{Expression of anti-p19 chimeric antibody}

Adherent CHO-K1 cells (ATCC, USA) were co-transfected with the purified plasmids containing heavy and light chains respectively, using Lipofectamine (Invitrogen, USA). Solutions of lipofectamine:DNA were prepared in a 2:1 molar ratio. Briefly, 75 $\mu$ l of DMEM:Ham'sF12 (1:1) (PAN Biotech, Germany) containing $2 \mu \mathrm{g}$ of pSecTag2B/ $\kappa-\kappa$ and $2 \mu \mathrm{g}$ of pcDNA 3.1(-)/ $\mu-\gamma$ were mixed with $75 \mu$ l of DMEM:Ham'sF12 (1:1) containing $8 \mu \mathrm{g}$ of Lipofectamine

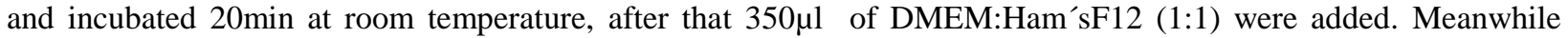
CHO-K1 cells were grown to $70 \%$ confluence $\left(37^{\circ} \mathrm{C}, 5 \% \mathrm{CO}_{2}\right)$, in wells of a 24 well plate (Greiner, Austria), after washing with DMEM: Ham'sF12 (1:1), the mixture of the complex Lipofectamine:DNA was added to each well and further incubated in the same conditions. The same procedure was performed with a solution of Lipofectamine without DNA as control. After $4 \mathrm{~h}$ incubation the supernatant was removed, fresh Ham's F12 medium supplemented with $10 \%$ Fetal Bovine Serum (FBS) (PAA Cell Culture Company, UK) was added and further incubated $72 \mathrm{~h}\left(37^{\circ} \mathrm{C}\right.$, $5 \% \mathrm{CO}_{2}$ ). Then supernatant was collected and tested by Western blotting. Selection was performed by adding together $1.4 \mathrm{mg} / \mathrm{ml}$ Neomicine (Sigma, USA) and $1 \mathrm{mg} / \mathrm{ml}$ Zeocine (Invitrogen, USA) into each change of fresh medium Ham'sF12 supplemented with 10\% FBS. Culture was expanded to flasks by standard procedures and chimeric antibody ch-3D7 was purified from supernatant using HiTrap Protein G HP (GE, USA) following manufacturer's instruction. 


\section{Monoclonal antibodies immuno-analysis}

ELISA, Western blot and immunochromatography were used to evaluate the diverse antibodies developed during this work. ELISA plates (Nalgene, Thermo Scientific, USA) were coated overnight $4^{\circ} \mathrm{C}$ with $100 \mu \mathrm{l}$ per well of: $20 \mu \mathrm{g} / \mathrm{ml} \mathrm{P}$ (MAMVE)-peptide or $5 \mu \mathrm{g} / \mathrm{ml}$ protein (BSA, HSA, KLH or recombinant p19) diluted in PBS. Next day, the plates were blocked with $200 \mu \mathrm{l}$ per well PBS-Tween 20 (Sigma,USA) $1 \% 1 \mathrm{~h}$ at $37^{\circ} \mathrm{C}$, and washed. The mouse serum samples $(100 \mu 1$ diluted $1 / 1000$ in PBS) or hybridoma supernatants $(100 \mu 1)$ were assayed by triplicates in each plate incubating $1 \mathrm{~h}$ at $37^{\circ} \mathrm{C}$, after washing anti-mouse: Horseradish Peroxidase conjugated (Sigma, USA) (diluted $1 / 5000$ in PBS) was added and incubated $1 \mathrm{~h}$ at $37^{\circ} \mathrm{C}$. Then the plates were washed and $\mathrm{H}_{2} \mathrm{O}_{2}$ with TMB (Thermo Scientific, USA) was used as substrate, absorbance at $450 \mathrm{~nm}$ was measured.

Western blot was performed as follows: Briefly rHis-p19 $(10 \mu \mathrm{g})$; rGST-19 $(10 \mu \mathrm{g})$ or BSA $(10 \mu \mathrm{g})$ were subjected to electrophoresis under denaturing conditions, and transferred into a nitrocellulose membrane $(0.45 \mu \mathrm{m}$ pore size, Amersham, USA). The membranes were then blocked with PBS-Tween $201 \%$ and incubated either with mouse monoclonal, or chimeric mouse-human monoclonal. Mouse hiperimmune anti-peptide serum was used as positive control. The mab-3D7 was pre-treated with DTT $\left(50 \mathrm{mM} \mathrm{30min,} 37^{\circ} \mathrm{C}\right)$ and iodoacetamide $\left(1 \mathrm{~h}, 37^{\circ} \mathrm{C}\right)$ to cause smooth reduction and fracture the pentamer enhancing the following step with the secondary antibody. The membranes were revealed with anti-mouse IgM alkaline phosphatase conjugate, or anti- human IgG alkaline phosphatase using 5-bromo-4-chloro-3-indolyl phosphate and Nitro Blue Tetrazolium (Sigma, USA) as substrate.

The reactivity of the chimeric antibody against the recombinant human IL-23 was assayed by immunochromatography. Briefly, two nitrocellulose membranes (Memb UniStart CN140 Polyester Backing 100ym, Sartorius Biotech, Germany) were coated either with 50ng recombinant IL-23 or 50ng BSA as negative control, then devices were finished by applying sample paper at the bottom (Millipore, Brazil) and the absorbent pad at the top of

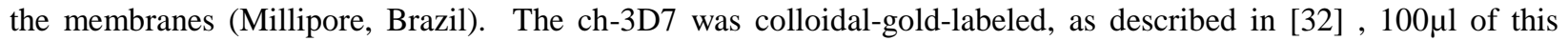
conjugate was added to the sample pad of each device and allow migrating for $5 \mathrm{~min}$.

\section{Competitive Inhibitory Test}

ELISA plate was prepared by coating with rHis-p19 $(5 \mu \mathrm{g} / \mathrm{mL}$ in PBS, $100 \mu \mathrm{l}$ per well) by overnight incubation at $4^{\circ} \mathrm{C}$ and blocked next day with PBS-Tween $201 \%\left(200 \mu \mathrm{l} /\right.$ well, $\left.37^{\circ} \mathrm{C}, 1 \mathrm{~h}\right) .200 \mu \mathrm{l}$ chimeric antibody ch-3D7 antibody or parental 3D7 monoclonal antibody were incubated with diverse concentration of rHis-p19 $(0.225,0.175$, $0.105,0.056$ and $0 \mathrm{M}$ ) at $37^{\circ} \mathrm{C}$, after $1 \mathrm{~h}$, each one was transferred to the ELISA plate (in duplicates) and incubated for additional 2h. After washing, anti- human IgG: Horseradish Peroxidase conjugated or anti-mouse IgM: Horseradish Peroxidase conjugated was used as secondary antibodies. $\mathrm{H}_{2} \mathrm{O}_{2}$ with TMB was used as substrate and absorbance at $450 \mathrm{~nm}$ was measured.

\section{Results and discussion}

In this work the following strategy was used. First the immunization of mice with a synthetic peptide derived from the sequence of protein $\mathrm{p} 19$ was investigated. Then, after generation of hybridoma secreting mAb reactive against recombinant protein $\mathrm{p} 19$, clone 3D7 secreting IgM subclass was used to generate a chimeric chain. Chimeric antibody (ch-3D7) was created using two eukaryotic expression plasmids carrying one the chimeric light construction and the other the chimeric heavy chain construction. Expression of chimeric antibody was performed by co-transfecting CHO-K1 cells with both plasmids.

\section{Generation of a monoclonal antibody anti-peptide able to recognize the recombinant human IL-23 biologically active}

An informatic analysis of potentially immunogenic regions in IL-23p19 was performed using online software, in order to investigate its immunogenicity and preliminarily evaluate a peptide as an effective antigen for mouse antibodies generation.

Hydrophilic domains that could be exposed on the surface were explored; for that purpose the p19 amino acid sequence was input and analyzed by the Hphob./Rao \&Argos method [33]; HPLC/TFA retention method [34]; and $\%$ buried residues method[35] in the ExPASy server (http://web.expasy.org/protscale) [25]. The three methods accordingly evidenced that the most hydrophilic region occupy amino acids located at positions 39-60 as shown in 
Figure 1. Based on that, and trying to avoid the presence of proline in the middle of the peptide, the string EEGDEETTNDVP between positions 39 and 50 was selected for synthesis. Finally, to verify that this sequence was exposed in the parent protein, it was explored within the hypothetical quaternary structure of IL-23, obtained from EMBL-EBI service (www.ebi.ac.uk, EMBL-EBI, Wellcome Genome Campus, UK), as shown in figure 2, from this approach it looks like the peptide is on the surface. Using Blast-p (http://blast.ncbi.nlm.gov/Blast.cgi?PAGE=Proteins) (National Center for Biotechnology Information, U.S. National Library of Medicine, Bethesda, USA) we corroborated that the sequence selected only showed homology with the human IL-23 (data not shown).

In order to make possible the generation of antibodies anti-hapten, the peptide was conjugated in various forms, and, to favor an oriented binding an arginine was added at the N-ter as a charged tag. Two carrier proteins and the peptide conjugated to itself were prepared and used to immunize the mice as described in materials and methods, additionally a synthetic polymer was used as carrier for ELISA plate coating to analyze hyperimmune anti-sera. ELISA outcome of hyperimmune anti-sera analysis showed that immunization resulted in response against both carrier proteins, as expected, but also against the peptide itself, furthermore the pool of anti-sera reacted positively against the complete protein by dot blot (data not shown) confirming that the peptide was exposed in the parent recombinant biologically active IL-23. Hybridoma supernatants were screened against recombinant rHis-p19 by ELISA, only three clones were positive, one of them named 3D7 was subcloned and further analyzed. Isotype of mab-3D7 was determined by capture ELISA, and resulted to be IgM subclass. Evaluated by western blot, mab-3D7 showed specific reactivity against recombinant rHis-p19 as shown in figure 3.

\section{Construction of the Eukaryotic Expression Vectors}

Initially, the murine MVк and $M V \mu$ variable genes of mab-3D7 were amplified by 5'RACE System from the total RNA of the hybridoma cells, using specific reverse primers designed from the available sequences of constant regions for both chains (Figure 4). The two gene fragments were inserted into Topo TA Cloning vector and sequenced. The light chain murine variable region is $408 \mathrm{bp}$ in length, containing the $72 \mathrm{bp}$ leading sequence. The $\mathrm{MV} \mu$ fragment is $399 \mathrm{bp}$ in length including the $60 \mathrm{bp}$ leading sequence. When the sequences were submitted to software analysis using IMGT/VQUEST (htpp://www.imgt.org) probable CDR regions could be predicted for both chains (Figure 5). Subsequently, two chimeric genes were constructed by overlap extension PCR, and cloned into two eukaryotic expression vectors. For this purpose, a set of eight primers (Table 1) were designed for the creation of the $\kappa-\kappa$ and $\mu-\gamma$ chimeric genes as schematized in figure 6 . To start with, murine variable chains and human constant chains were amplified by PCR (named PCR 1 and PCR 2 in the figure). The forward primers for MVк and $\mathrm{MV} \mu$ variable strings include the KOZAC sequence at the 5' end, and forward primers for human constant $\kappa$ and $\gamma$ chains include, at the 5' end, the corresponding complementary sequence of the 3 ' end of variable murine sequence for the light and heavy chain in that order. PCR 1 and PCR 2 results showed each, a sole product of ca. 500bp for

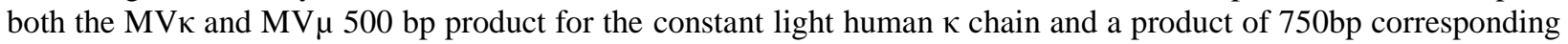
to the constant heavy human $\gamma$ chain (Figure 7). Afterward, an overlap extension PCR mix (PCR 3 in the figure 6) was set for each chimeric construction, using: i) equimolar amounts of the corresponding PCR products purified from agarose gels ( $\mathrm{MV} \kappa+$ human $\kappa)$ or $(\mathrm{MV} \mu+$ human $\gamma)$, ii) a full forward primer matching the variable 5' region, iii) a full length reverse primer matching the constant 3 ' region, and iv) a Tm according to the complementary region between the light and heavy chain. The product obtained for the chimeric light chain was inserted into pSecTag2B vector to form the chimeric light chain antibody vector (pSecTag2B/k-k) and sequenced, in the same way, the chimeric heavy chain was cloned into pcDNA 3.1 (-) (pcDNA3.1(-)/ $\mu-\gamma$ and sequenced. The sequences obtained, submitted to informatic analysis, showed a length of 733bp for the light chain and $1157 \mathrm{bp}$ for the heavy chain and absence of mutations in comparison with the parent monoclonal antibody.

\section{Transfection of the CHO-K1 Cells}

Purified pSecTag2B $/ \kappa-\kappa$ and pcDNA3.1(-)/ $\mu-\gamma$ plasmids were used to co-transfect CHO-K1 cells by means of Lipofectamina complex. 72h after the transfection, the culture was assayed for the transient expression of ch-3D7 by Western Blot confirming the presence of human IgG in the culture supernatant. Stable transfectants were achieved by culturing in selective media. The clones that survived were expanded and culture to production of ch-3D7. Expression level obtained was as high as about $8 \mathrm{mg} / \mathrm{mL}$. 


\section{Characterization of the Expressed Antibody}

We demonstrate that ch-3D7, which was generated against a synthetic peptide, binds IL-23p19 as well as the complete IL-23 (recombinant forms) using Western Blot and immunochromatography (Figure 8). To further analyze the chimeric antibody, a competitive inhibitory assay was performed to determine the dissociation constant of antibody-antigen complex, following the method described by Friguet et al. [36]. Both ch-3D7 and mab-3D7 were allowed reacting with recombinant rHis-19 in solution, and then the amount of unbound antibody was measured by classic indirect ELISA. In figure 9 are shown the results of $\mathrm{OD} / \mathrm{OD}_{0}$ vs ng of protein showing a typical sigmoid curve. $K_{D}$ was determined from the slope of the curve v/a [37] v defined by method described by Friguet et al. [37] and considering de Scarchard equation. From this, $K_{A}$ determined as $1 / K_{D}$ was calculated for ch-3D7 and mab-3D7, being of $6 \times 10-{ }^{5} \mathrm{M}$ for the ch-3D7 and $5 \times 10-{ }^{5} \mathrm{M}$ for mab-3D7. Regarding those values, chimerization did not affect the affinity of the parent antibody, though low, are in accordance with the class of the parental monoclonal antibody.

\section{Conclusions}

Targeted therapy using specific antibodies is nowadays an existing option for several chronic diseases. In this work we generated a chimeric antibody that recognizes specifically the minor subunit of IL-23, an interleukin with demonstrated pathogenic character in several autoimmune diseases. Firstly, a computational study of potentially exposed regions of IL-23p19 was done in order to choose a peptide as epítope for immunization and subsequent generation of monoclonal antibodies. Once the hybridoma secreting specific antibody was selected, the sequences of the monoclonal antibody variable chains were isolated from genetic material and cloned into two eukaryotic vectors, containing the corresponding constant heavy or light chain for human immunoglobulin. Our eukaryotic expression system, concerned the transfection of CHO-K1 cells with two constructions simultaneously, one of them carrying the chimeric light chain and the codifying resistance to Zeocin and the other delivering the chimeric heavy construction and resistance to Neomycin. Thus, after co-transfection and addition of both antibiotics to favor a selective pressure, only those stably transfected with both plasmid cells would survive. The chimeric chains are then translated, secreted and assembly to form the quaternary structure of the immunoglobulin molecule. Expression of soluble protein into the culture medium was evaluated by ELISA and Western Blot and the expected reactivity against p-19 was demonstrated. Reactivity against human recombinant IL-23 biologically active was evaluated by non-denaturing methods showing that the antibody may be useful recognizing the interleukin in its native form. Affinity constant for the produced chimeric antibody calculated against the recombinant form of p19 resulted in $10^{-5}$ $\mathrm{M}$, though low, is in accordance with values expected for antibodies of subclass $\mathrm{M}$, as is the monoclonal parental antibody. Having corroborated the specificity of the new antibody it could be of potential use in therapeutics, the necessary improvement of affinity could be performed by bioinformatic analysis of the sequence and subsequent modification[10].

\section{References}

1. Gavilondo, J.V. and J.W. Larrick, Antibody engineering at the millennium. Biotechniques, 2000. 29(1): p. 128-32, 1346, 138 passim.

2. Schroff, R.W. and H.C. Stevenson, Human Immune Responses to Murine Monoclonal Antibodies, in Monoclonal Antibody Therapy of Human Cancer, K.A. Foon and A.C. Morgan, Editors. 1985, Springer US: Boston, MA. p. 121 138.

3. Carter, P., Improving the efficacy of antibody-based cancer therapies. Nat Rev Cancer, 2001. 1(2): p. 118-29.

4. $\quad$ Presta, L.G., Engineering antibodies for therapy. Curr Pharm Biotechnol, 2002. 3(3): p. 237-56.

5. Morrison, S.L., et al., Chimeric human antibody molecules: mouse antigen-binding domains with human constant region domains. Proceedings of the National Academy of Sciences, 1984. 81(21): p. 6851-6855.

6. $\quad$ Carter, P.J., Potent antibody therapeutics by design. Nat Rev Immunol, 2006. 6(5): p. 343-57.

7. Jones, P.T., et al., Replacing the complementarity-determining regions in a human antibody with those from a mouse. Nature, 1986. 321(6069): p. 522-5.

8. Verhoeyen, M., C. Milstein, and G. Winter, Reshaping human antibodies: grafting an antilysozyme activity. Science, 1988. 239(4847): p. 1534-6.

9. Hoogenboom, H.R., Selecting and screening recombinant antibody libraries. Nat Biotechnol, 2005. 23(9): p. $1105-16$.

10. Khoo, Y.L., S.H. Cheah, and H. Chong, Humanization of chimeric anti-CD20 antibody by logical and bioinformatics approach with retention of biological activity. Immunotherapy, 2017. 9(7): p. 567-577.

11. Oppmann, B., et al., Novel p19 protein engages IL-12p40 to form a cytokine, IL-23, with biological activities similar as well as distinct from IL-12. Immunity, 2000. 13(5): p. 715-25. 
IRA-International Journal of Applied Sciences

12. Floss, D.M., et al., Insights into IL-23 biology: From structure to function. Cytokine \& Growth Factor Reviews, 2015. 26(5): p. 569-578.

13. Harrington, L.E., P.R. Mangan, and C.T. Weaver, Expanding the effector CD4 T-cell repertoire: the Th17 lineage. Curr Opin Immunol, 2006. 18(3): p. 349-56.

14. Teng, M.W.L., et al., IL-12 and IL-23 cytokines: from discovery to targeted therapies for immune-mediated inflammatory diseases. Nat Med, 2015. 21(7): p. 719-729.

15. Pistoia, V., The IL-12/IL-23 Cytokine Family A2 - Ratcliffe, Michael J.H, in Encyclopedia of Immunobiology. 2016, Academic Press: Oxford. p. 525-533.

16. Croxford, A.L., P. Kulig, and B. Becher, IL-12-and IL-23 in health and disease. Cytokine \& Growth Factor Reviews, 2014. 25(4): p. 415-421.

17. Lee, E., et al., Increased expression of interleukin 23 p19 and p40 in lesional skin of patients with psoriasis vulgaris. $\mathrm{J}$ Exp Med, 2004. 199(1): p. 125-30.

18. Wang, W., et al., C57BL/6 mice genetically deficient in IL-12/IL-23 and IFN-gamma are susceptible to experimental autoimmune myasthenia gravis, suggesting a pathogenic role of non-Th1 cells. J Immunol, 2007. 178(11): p. $7072-80$.

19. Joosten, L.A., et al., Association of interleukin-18 expression with enhanced levels of both interleukin-1beta and tumor necrosis factor alpha in knee synovial tissue of patients with rheumatoid arthritis. Arthritis Rheum, 2003. 48(2): p. 339-47.

20. Fujino, S., et al., Increased expression of interleukin 17 in inflammatory bowel disease. Gut, 2003. 52(1): p. 65-70.

21. Schmidt, C., et al., Expression of interleukin-12-related cytokine transcripts in inflammatory bowel disease: elevated interleukin-23p19 and interleukin-27p28 in Crohn's disease but not in ulcerative colitis. Inflamm Bowel Dis, 2005. 11(1): p. 16-23.

22. Stallmach, A., et al., Cytokine/chemokine transcript profiles reflect mucosal inflammation in Crohn's disease. Int $\mathbf{J}$ Colorectal Dis, 2004. 19(4): p. 308-15.

23. Hueber, W., et al., Secukinumab, a human anti-IL-17A monoclonal antibody, for moderate to severe Crohn's disease: unexpected results of a randomised, double-blind placebo-controlled trial. Gut, 2012. 61(12): p. 1693-700.

24. Hepworth, M.R., et al., Innate lymphoid cells regulate CD4+ T-cell responses to intestinal commensal bacteria. Nature, 2013. 498(7452): p. 113-7.

25. Gasteiger E., H.C., Gattiker A., Duvaud S., Wilkins M.R., Appel R.D., Bairoch A.;, Protein Identification and Analysis Tools on the ExPASy Server;. 2005: John M. Walker (ed): The Proteomics Protocols Handbook, Humana Press (2005).

26. Ladaviere, C., et al., Electrostatically driven immobilization of peptides onto (Maleic anhydride-alt-methyl vinyl ether) copolymers in aqueous media. Bioconjug Chem, 2000. 11(2): p. 146-52.

27. Cowley, J.V.G., Anticuerpos monoclonales. 1995: Elfos Scientiae.

28. Petersen, T.N., et al., SignalP 4.0: discriminating signal peptides from transmembrane regions. Nat Methods, 2011. 8(10): p. 785-6.

29. Brochet, X., M.P. Lefranc, and V. Giudicelli, IMGT/V-QUEST: the highly customized and integrated system for IG and TR standardized V-J and V-D-J sequence analysis. Nucleic Acids Res, 2008. 36(Web Server issue): p. W503-8.

30. Higuchi, R., B. Krummel, and R.K. Saiki, A general method of in vitro preparation and specific mutagenesis of DNA fragments: study of protein and DNA interactions. Nucleic Acids Res, 1988. 16(15): p. 7351-67.

31. Langjahr-Penayp P., Clonamienot de la secuencia de DNA codificante de los dominios variables funcionales y quimerización de un anticuerpo monoclonal anti-factor de necrosis tumoral humano in ICBM, Facultad de Medicina. 2006, Universidad de Chile: Universidad de Chile. p. 78.

32. Hermanson, G.T., Chapter 20 - Antibody Modification and Conjugation, in Bioconjugate Techniques (Third edition). 2013, Academic Press: Boston. p. 867-920.

33. Rao M.J. K., A.P., Amino acid scale: Membrane buried helix parameter. Biochim. Biophys. Acta, 1986. 869: p. 197214.

34. Browne, C.A., H.P. Bennett, and S. Solomon, The isolation of peptides by high-performance liquid chromatography using predicted elution positions. Anal Biochem, 1982. 124(1): p. 201-8.

35. Janin, J., Surface and inside volumes in globular proteins. Nature, 1979. 277(5696): p. 491-2.

36. Friguet, B., et al., Measurements of the true affinity constant in solution of antigen-antibody complexes by enzymelinked immunosorbent assay. J Immunol Methods, 1985. 77(2): p. 305-19.

37. Chen, Y., et al., Anti-IL-23 therapy inhibits multiple inflammatory pathways and ameliorates autoimmune encephalomyelitis. J Clin Invest, 2006. 116(5): p. 1317-26. 


\section{TABELS \& FIGURES Section}

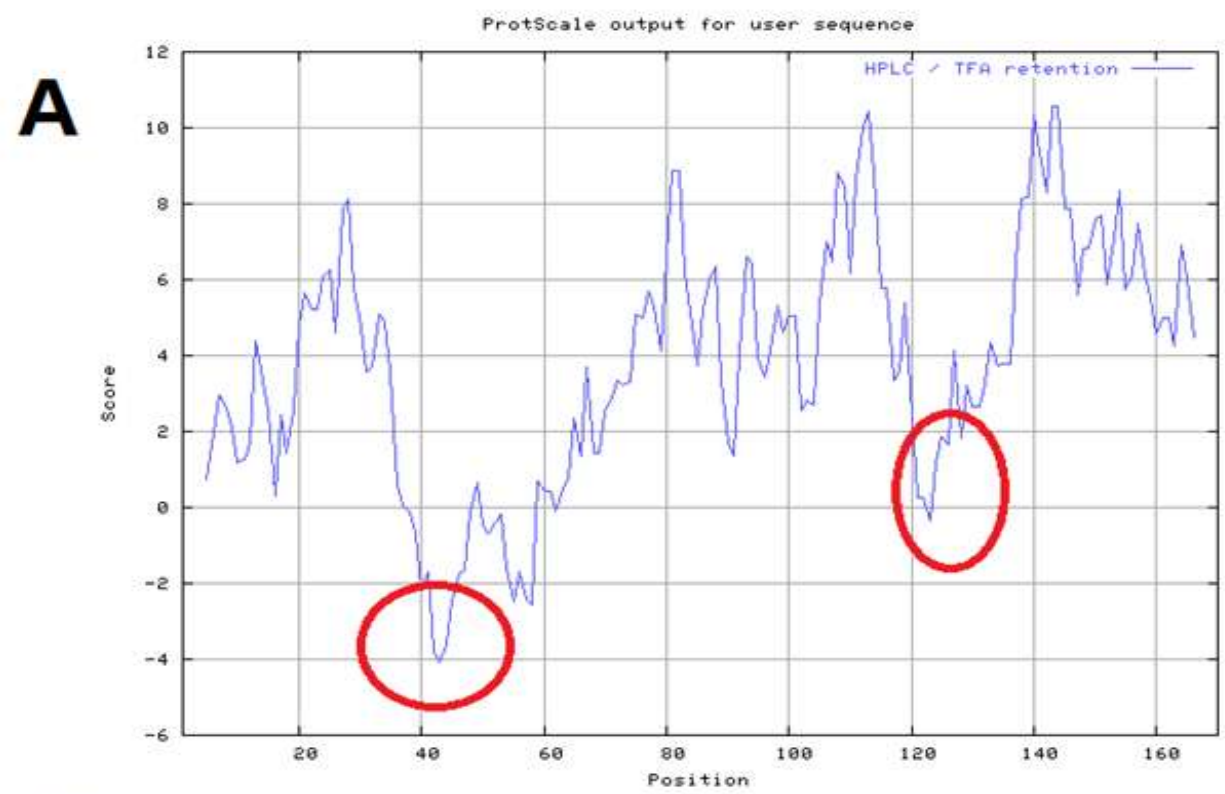

B

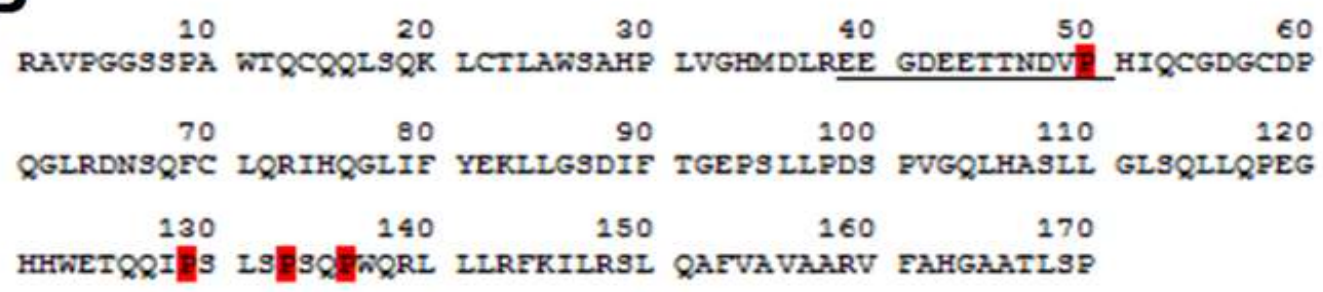

Figure 1. Informatic analysis of the amino acid sequence of IL23-p19. (A) Hydrophilic region prediction using HPLC/TFA retention method[34]. (B) Amino acid sequence of human IL-23p19 (Genebank NM_016585)[11]. The selected peptide for synthesis is underlined. 


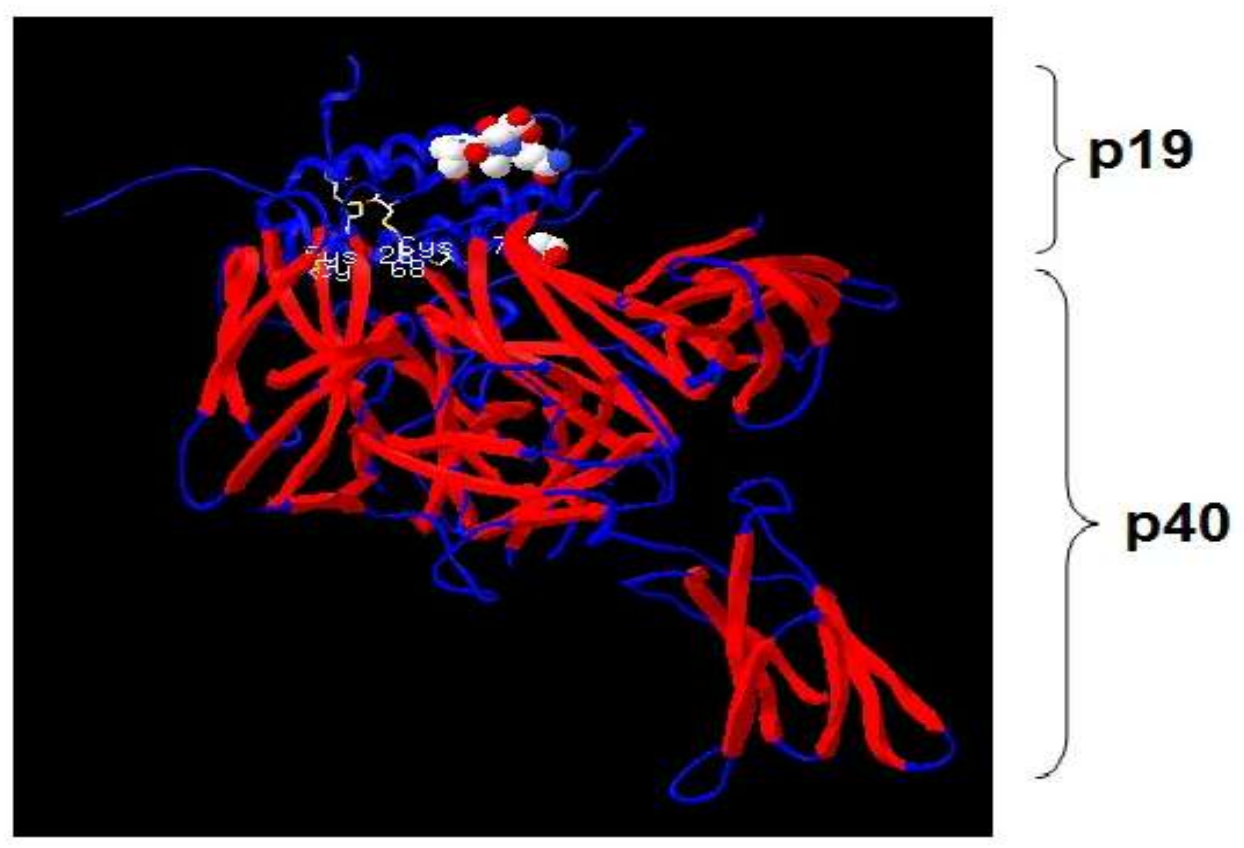

Figure 2. Quaternary structure of IL-23 (EMBL-EBI (www.ebi.ac.uk/). p19 subunit and p40 subunit are signaled; Balls: peptide between amino acids 39-50, candidate for synthesis.

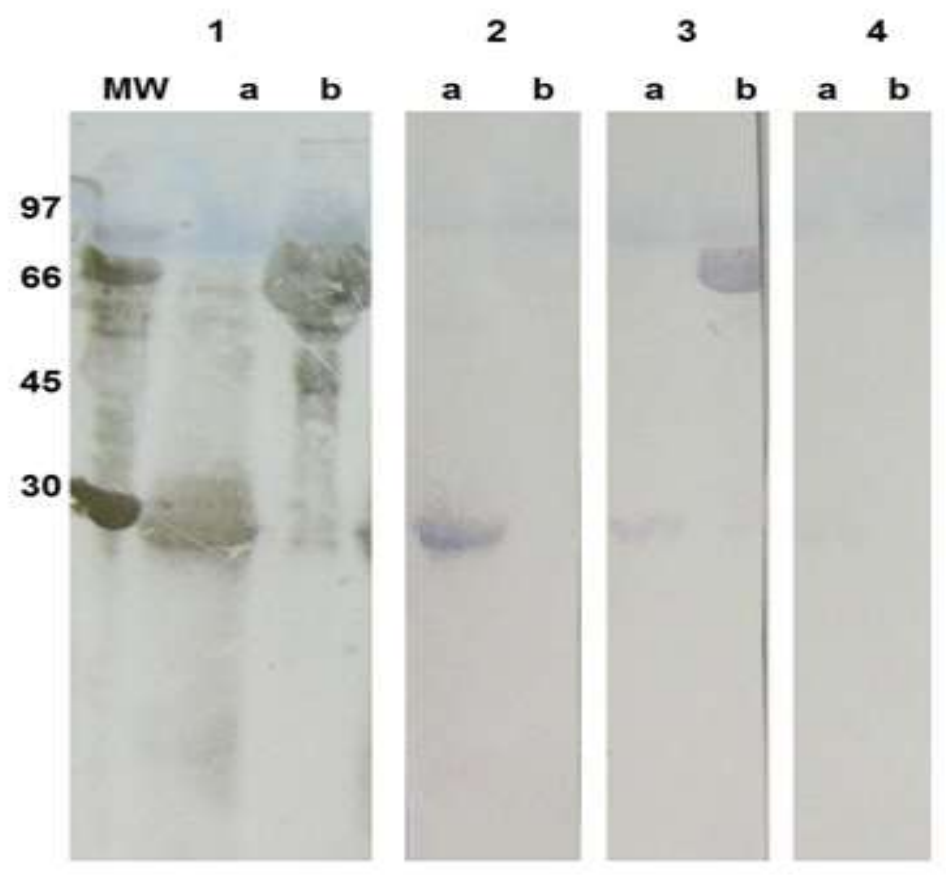

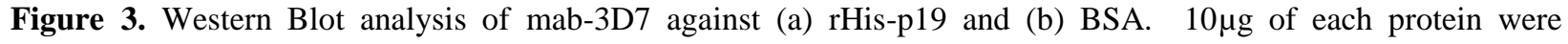
submitted to SDS-PAGE 12\% and transferred to a nitrocellulose membrane. 1: membrane stained with amido black; 2: membrane incubated with mab-3D7; 3: membrane incubated with mouse hyperimmune anti-peptide serum; 4 : Control for the anti-mouse alkaline phosphatase conjugate. The mouse serum recognizes mostly the BSA used as 
carrier, but also the recombinant rHis-p19 by means of the anti-peptide antibodies successfully generated. The monoclonal antibody recognizes specifically the $\mathrm{p}-19$ subunit.

A

CLUSTAL W (1.83) multiple sequence alignment

M14099.1 GA GAGTCAGTCCTTCCCAAATGTCTTCCCCCTCGTCTCCTGCGAGAGCCCCCTGTRTGAT \$50905.1 GAGAGTCAGTCCTTCCCAAATGTCTTCCCCCTCGTCTCCTGCGAGAGCCCCCTGTETGAT J00442.1

J00441.1 GAGAGTCAGTCCTTCCCAAATGTCTTCCCCCTCGTCTCCTGCGAGAGCCCCCTGTCTGAT GAGAGTCAGTCCTTCCCAAATGTCTTCCCCCTCGTCTCCTGCGAGAGCCCCCTGTCTGAT GAGAGTCAGTCCTTCCCAAATGTCTTCCCCCTCGTCTCCTGCGAGAGCCCCCTGTETGAT

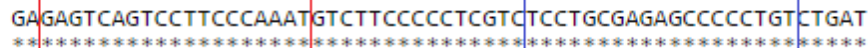

X05794.1

M14099.1 $\$ 50905.1$

AAGAATCTGGTGGCCATGGGCTGCCTGGCCCGGGACTTCCTGCCCAGCACCATTTCCTTC AAGAATCTGGTGGCCATGGGCTGCCTGGCCCGGGACTTCCTGCCCAGCACCATTTCCTTC AAGAATCTGGTGGCCATGGGCTGCCTGGCCCGGGACTTCCTGCCCAGCACCATTTCCTTC AAGAATCTGGTGGCCATGGGCTGCCTGGCCCGGGACTTCCTGCCCAGCACCATTTCCTTC AAGAATCTGGTGGCCATGGGCTGCCTGGCCCGGGACTTCCTGCCCAGCACCATTTCCTTC AAGAATCTGGTGGCCATGGGCTGCCTGGCCCGGGACTTCCTGCCCAGCACCATTTCCTTC

J00441.1

X03690. *****************************************************************1

M14099.1

ACCTGGAACTACCAGAACAACACTGAAGTCATCCAGGGTATCAGAACCTTCCCAACACTG ACCTGGAACTACCAGAACAACACTGAAGTCATCCAGGGTATCAGAACCTTCCCAACACTG ACCTGGAACTACCAGAACAACACTGAAGTCATCCAGGGTATCAGAACCTTCCCAACACTG ACCTGGAACTACCAGAACAACACTGAAGTCATCCAGGGTATCAGAACCTTCCCAACACTG ACCTGGAACTACCAGAACAACACTGAAGTCATCCAGGGTATCAGAACCTTCCCAACACTG

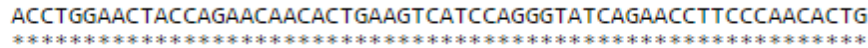

$\mathrm{X} 03690.1$

B

CLUSTAL W (1.83) multiple sequence alignment

$\mathrm{X} 67011.1$

$\mathrm{x} 67006.1$

$\mathrm{X} 67012.1$

$\mathrm{X} 67004.1$

$\mathrm{X} 67005.1$

- - -ACTGAAATGGAGCCCTTCCTTGTTACTTCATACCATCCTCTGTGCTTCCTTCCTCAG TACACTGAAATGGAGCCCTTCCTTGTTACTTCATACCATCCTCTGTGCTTCCTTCCTCAG - - ACTGAAATGGAGCCCTTCCTTGTTACTTCATACCATCCTCTGTGCTTCCTTCCTCAG - - ACTGAAATGGAGCCCTTCCTTGTTACTTCATACCATCCTCTGTGCTTCCTTCCTCAG - - - ACTGAAATGGAGCCCTTCCTTGTTACTTCATACCATCCTCTGTGCTTCCTTCCTCAG ***********************************************************

$\mathrm{X} 67011.1$ $\mathrm{X} 67006.1$ $\mathrm{X} 67012.1$

GGGCTGATGCTGCACCACTGTATCEATCTTCCCACCATCCAGTGAGCAGTTAACATCTGG GGGCTGATGCTGCCCAACTGTATCCATCTTCCCACCATCCAGTGAGCAGTTAACATCTGG GGGCTGATGCTGCACCACTGTATCEATCTTCCCACCATCCAGTGAGCAGTTAACATCTGG GGGCTGATGCTGCACCACTGTATCCATCTTCCCACCATCCAGTGAGCAGTTAACATCTGG X67005.1 GGGCTGATGCTGCACCACTGTATCCATCTTCCCACCATCCAGTGAGCAGTTAACATCTGG

X67011.1 AGGT GCCTCAGTCGTGTGCTTCT TGAACAACTCTACCCCAGAGACATCAATGTCAAGTGG $\mathrm{X} 67006.1$ $\mathrm{X} 67012.1$

$\mathrm{x} 67004.1$ AGGTGCCTCAGTCGTGTGCTTCT TGAACAACTCTACCCCAGAGACATCAATGTCAAGTGG
AGGTGCCTCAGTCGTGTGCTTCTTGAACACTTCTACCCCAAAGACATCAATGTCAAGTGG AGGTGCCTCAGTCGTGTGCTTCT TIGACAACTCTACCCCAAAGACATCAATGTCAAGTGG AGGTGCCTCAGTCGTGTGCTTCT TGAACAACTCTACCCCAAAGACATCAATGTCAAGTGG

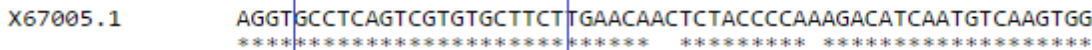

Figure 4. Alignment of sequences for the murine $\mu$ and $\kappa$ constant chains using Clustal W (http://embnet.vitalit.ch/software/ClustalW.html/). (A) murine $\mu$ fragment; (B) murine $\kappa$ chain. In boxes are denoted the regions used to design the antisense primers for the isolation of total RNA from hybridoma cells in combination with the 5'RACE System for Rapid Amplification of cDNA Ends. 
Table 1. List of primers designed for the overlap extension PCR. Restriction sites for NheI or BamHI enzymes are underlined; Kozak sequence is in italics in VmuMF and VкMF. Complementary sequences of corresponding variable chain are in black type in forward primers FusVmuM/CgHF and FusV $\kappa \mathrm{M} / \mathrm{CkHF}$ for overlap extension.

\begin{tabular}{|c|c|c|c|c|}
\hline Primer Name & Sequence $5^{\prime}-3^{\prime}$ & & & \\
\hline VmuMF & AAAAGCTAGCCACCATGGGATGGAGCTCTA & Sense & $\begin{array}{l}\text { Murine } \\
\text { chain }\end{array}$ & $\mu$ \\
\hline FusVmuM/CgHR & TGAGGAGACTGTGAGAGTGGT & Antisense & $\begin{array}{l}\text { Murine } \\
\text { chain }\end{array}$ & $\mu$ \\
\hline VкMF & AAAAGCTAGCACCATGATGTCCTCTGCTC & Sense & $\begin{array}{l}\text { Murine } \\
\text { chain }\end{array}$ & $\kappa$ \\
\hline FusVкM/CкHR & GGATACAGTTGGTGCAGCAT & Antisense & $\begin{array}{l}\text { Murine } \\
\text { chain }\end{array}$ & $\kappa$ \\
\hline FusVmuM/CgHF & ACCACTCTCACAGTCTCCTCACAAGGGCCC & $\begin{array}{l}\text { Sense } \\
\text { overlap }\end{array}$ & $\begin{array}{l}\text { Humany1 } \\
\text { chain }\end{array}$ & \\
\hline Cg1HR & GGGGGGATCCTCATTTACCCGGAGAC & Antisense & $\begin{array}{l}\text { Humany1 } \\
\text { chain }\end{array}$ & \\
\hline FusVкM/CкHF & ATGCTGCACCAACTGTATCCACTGTGGCTGCA & $\begin{array}{l}\text { Sense } \\
\text { overlap }\end{array}$ & $\begin{array}{l}\text { Human } \\
\text { chain }\end{array}$ & $\kappa$ \\
\hline CKHR & CCCCCGGATCC & Antisense & $\begin{array}{l}\text { Human } \\
\text { chain }\end{array}$ & $\kappa$ \\
\hline
\end{tabular}

A Nucleic and aminoacid sequences of $\kappa$ chain variable region of 3D7

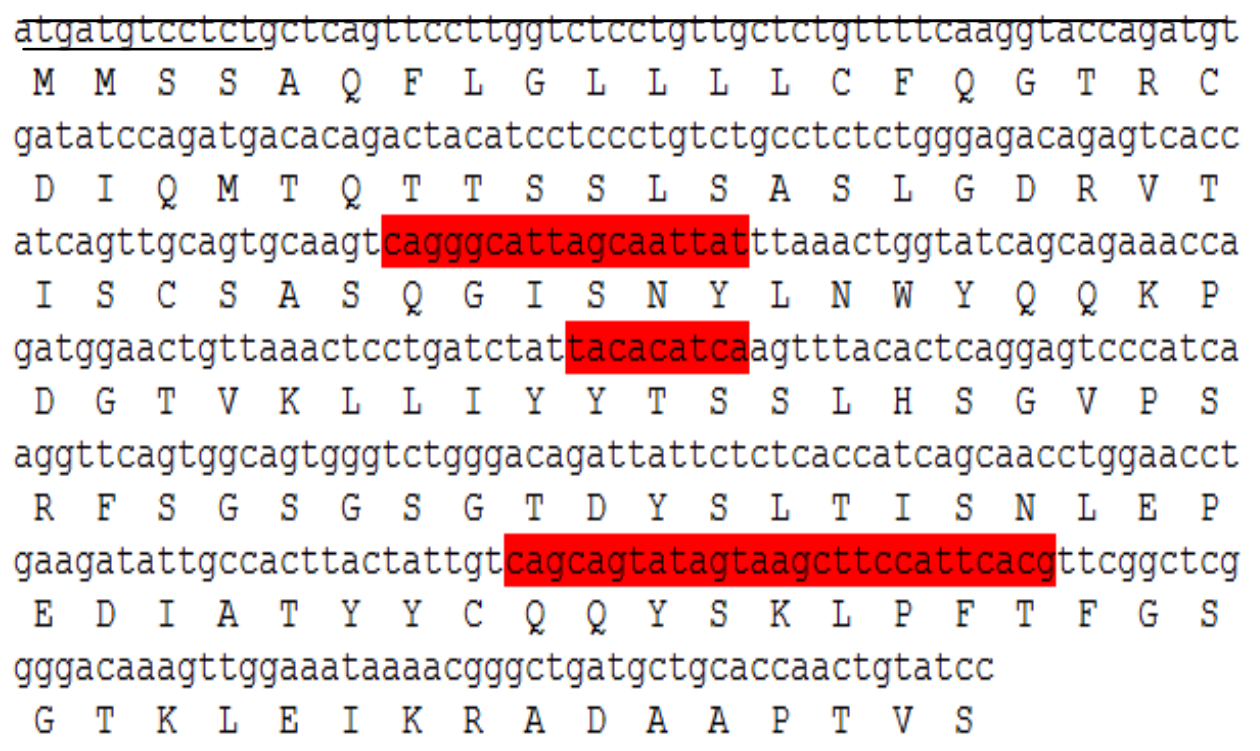


B Nucleic and aminoacid sequences of $\mu$ chain variable region of 3D7

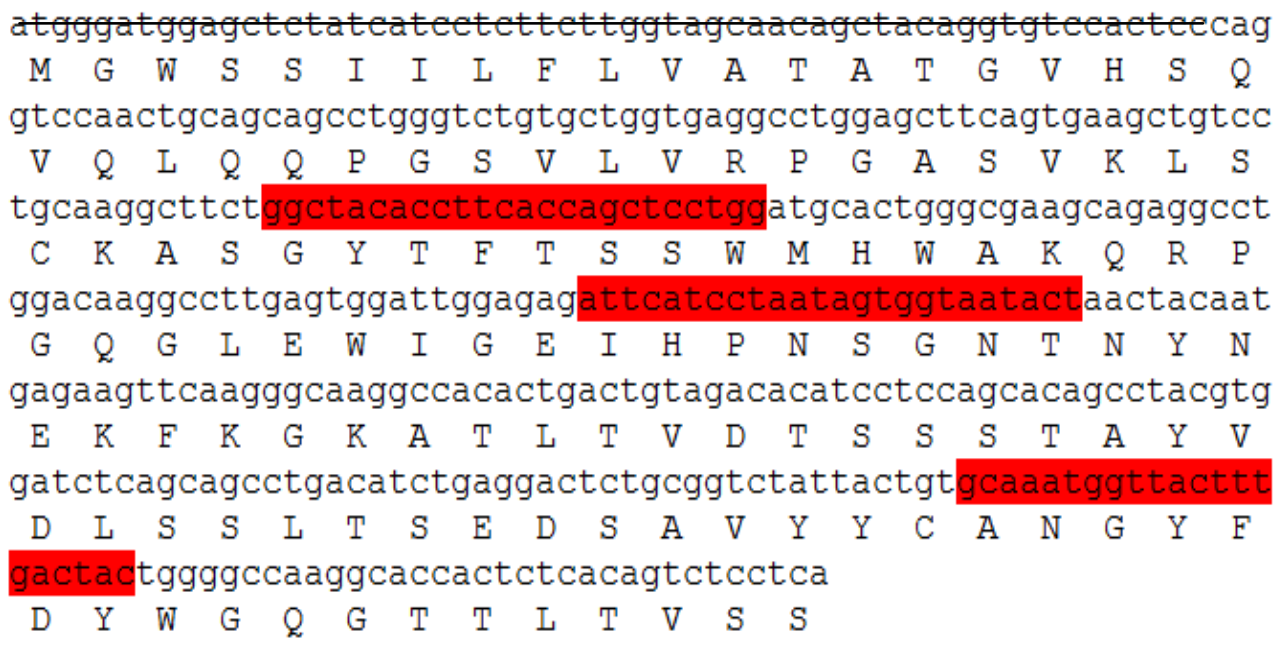

Figure 5. Nucleic acid and amino acid sequence of variable light and variable heavy chains of 3D7. Signal peptides are underlined, predicted CDR1; CDR2 and CDR3 are highlighted. Informatic analysis was performed by using Translate Tool, SignalP 4.0 (http://www.expasy.org/), IMGT/V-QUEST (http://www.imgt.org).
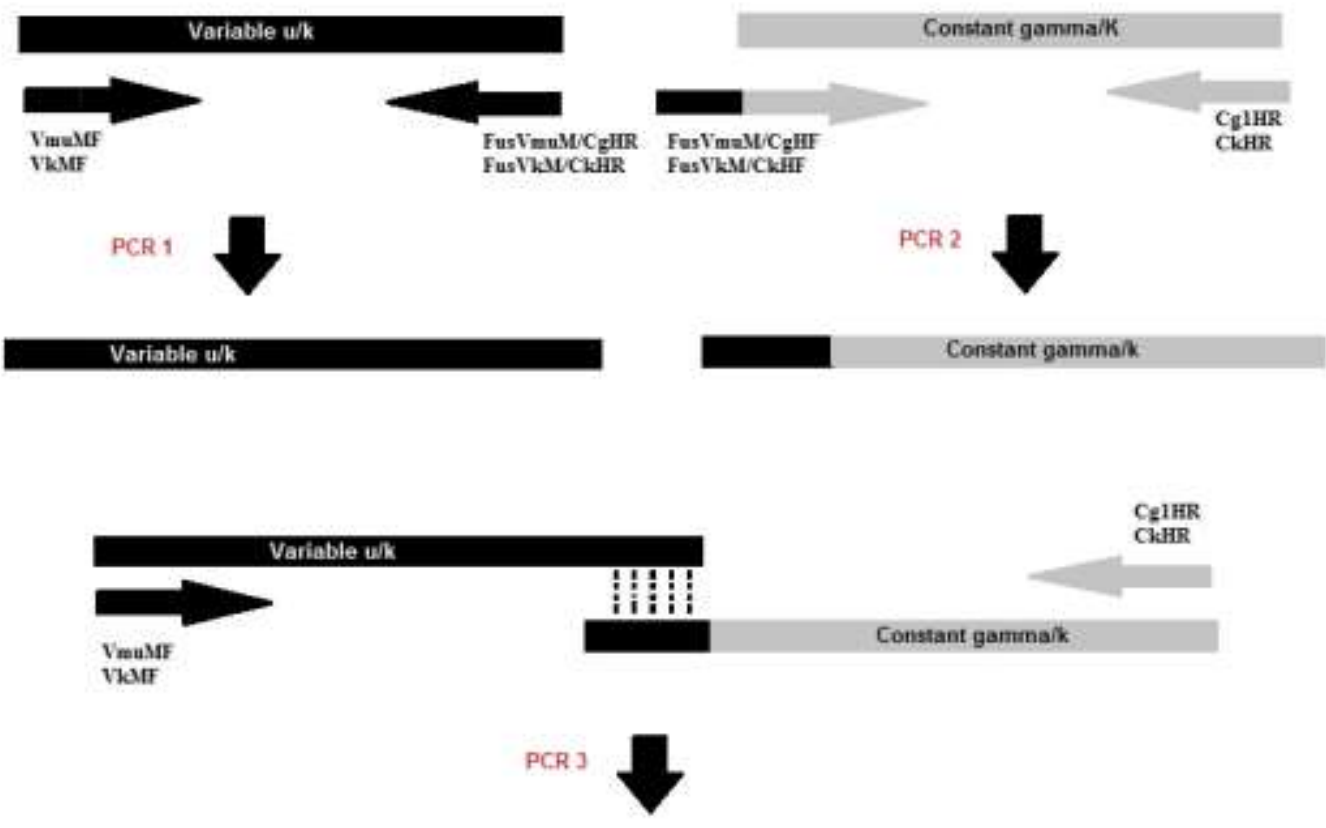
Figure 6. Schematic representation of the construction of chimerical DNA fragments encoding Heavy and Light Immunoglobulin chains. Chimerical $\mu-\gamma$ chain was amplified at a $\mathrm{Tm}=53^{\circ} \mathrm{C}$ and chimerical $\kappa-\kappa$ chain was amplified at a $\mathrm{Tm}=51^{\circ} \mathrm{C}$. For the overlap extension PCR reactions, equimolar amounts of corresponding DNA fragments were used in a $25 \mu 1$ mix with final mass of 3 ng of DNA.

A
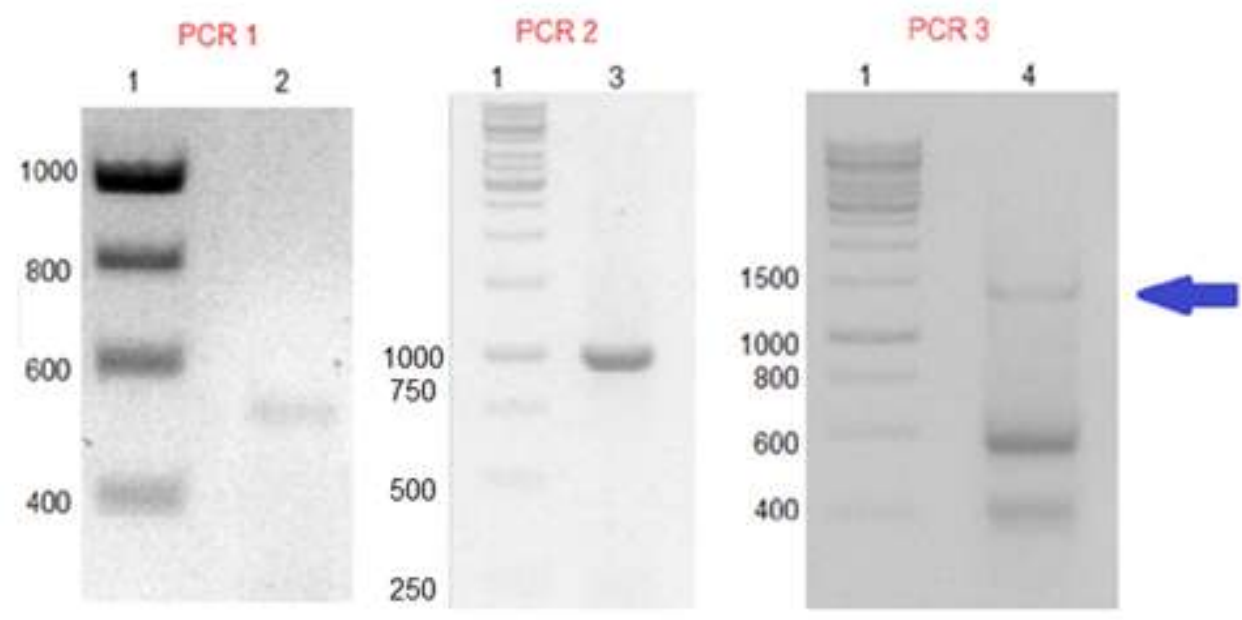

B
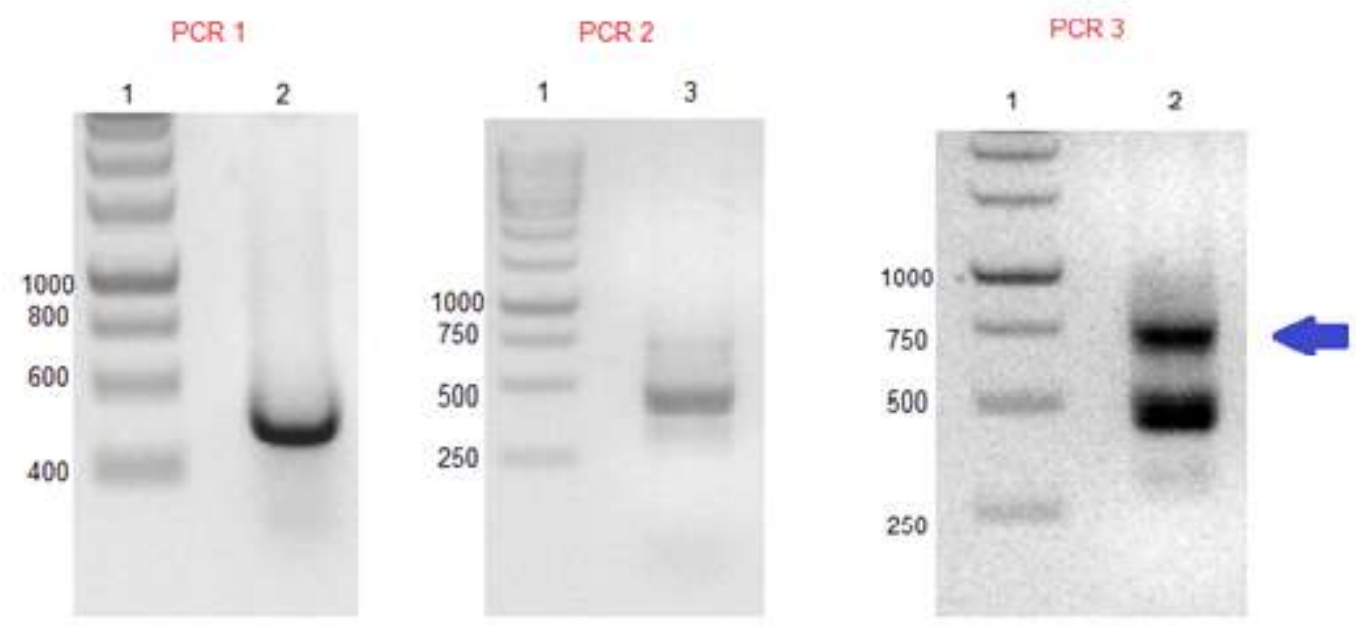
Figure 7. PCR steps for the construction of the chimeric chains. (A) ch-3D7 $\mu-\gamma$ Lane 1: DNA Ladder (bp), Lane 2: Murine 3D7 V $\mu$ chain ; lane 3: human $\gamma$; lane 4: overlap extension PCR (VM $\mu$ - human $\gamma$ ) using products of

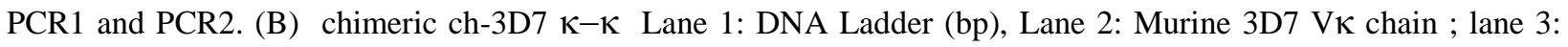

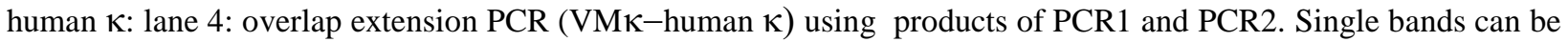
observed in the amplification of murine and human immunoglobulin chains, some incomplete or unspecific sub products appear after the overlap extension reactions. Complete and specific $\mu-\gamma$ and $\kappa-\kappa$ products are denoted with arrows.

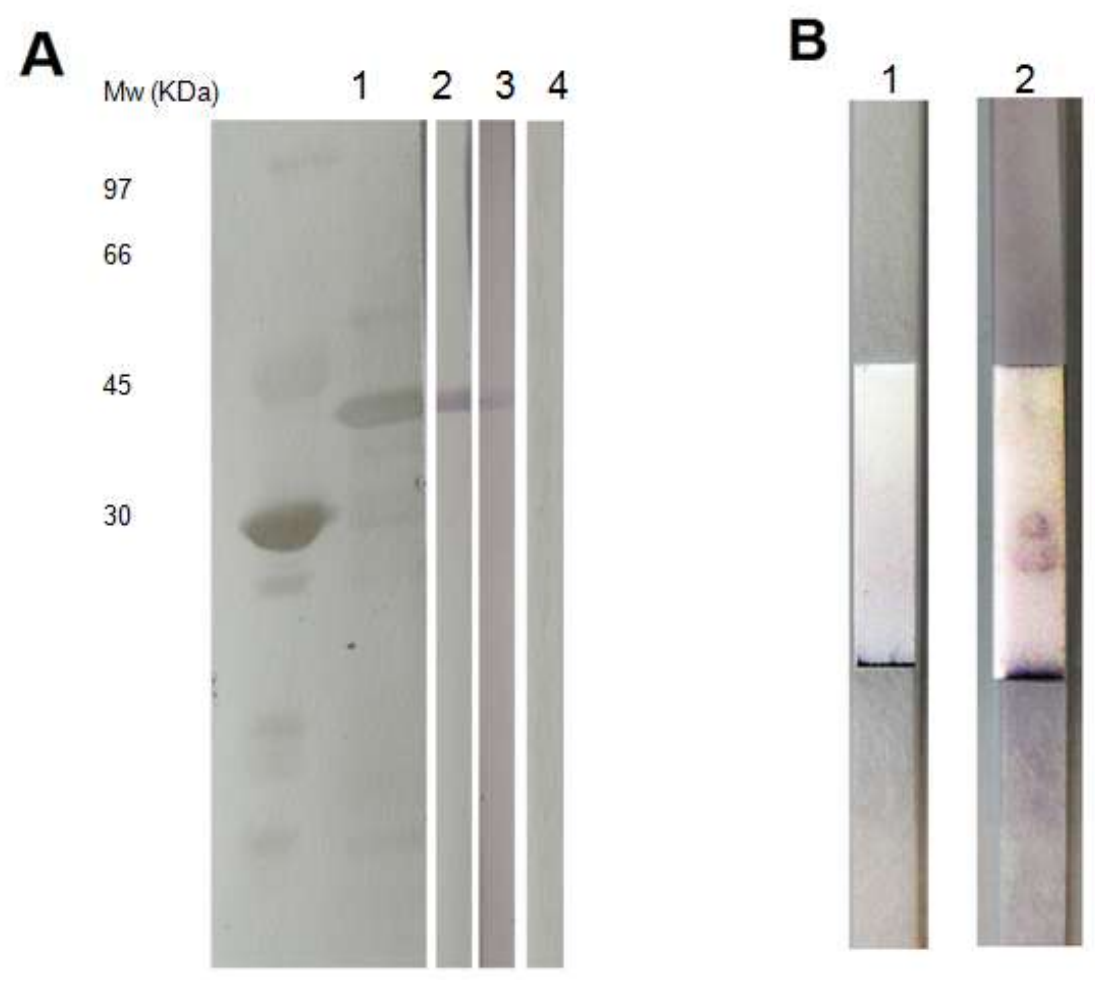


Figure 8. (A) Western Blot analysis of mab-3D7 and ch-3D7 against rGST-p19. 10 $\mu$ g of protein was submitted to SDS-PAGE $12 \%$ and transferred to a nitrocellulose membrane. 1: membrane stained with amido black; 2: membrane incubated with mab-3D7; 3: membrane incubated with ch-3D7; 4: Control for alkaline phosphatase conjugates. In lines 2 and 3 a band corresponding to the recombinant fusion protein GST-p19 is recognized by both mouse and chimeric antibodies, demonstrating that the chimeric form retains the reactivity of the parent antibody. (B) Immunochromatographic analysis of ch-3D7 against 1: BSA, 2: human recombinant IL-23. Five minutes after applying $100 \mu \mathrm{l}(5 \mathrm{ng} / \mu \mathrm{l})$ of gold labeled-ch-3D7 reactivity was observed against IL-23 .

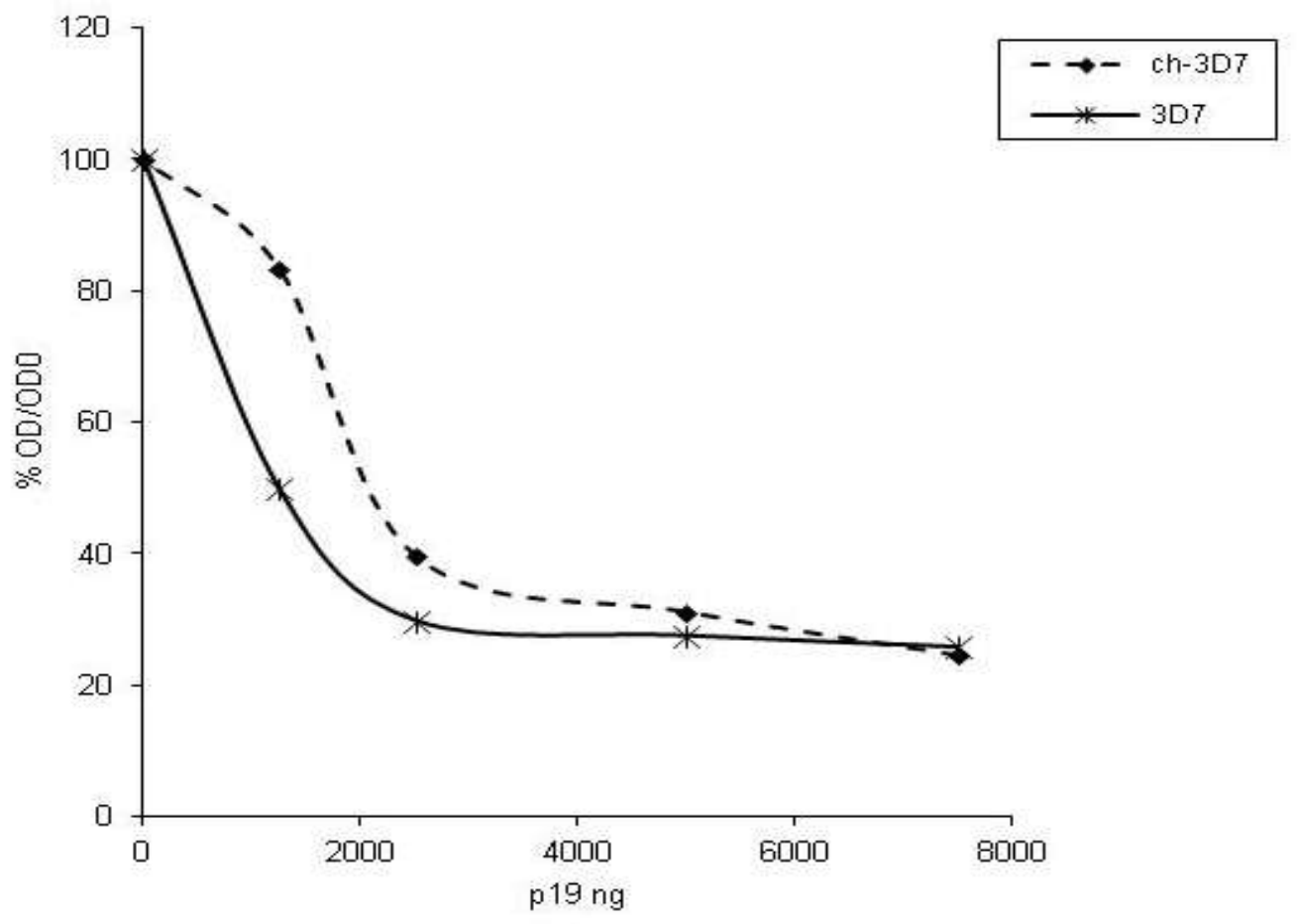


Figure 9. Graphic representation of the results of the competitive inhibitory test. (A) Competitive ELISA. (B) Scatchard plots of the binding of 3D7 and ch-3D7 to rHis-p19 measured by ELISA. (v) is the fraction of bound antibody and (v/a) the concentration of free antigen at equilibrium, as defined by Friguet et al.

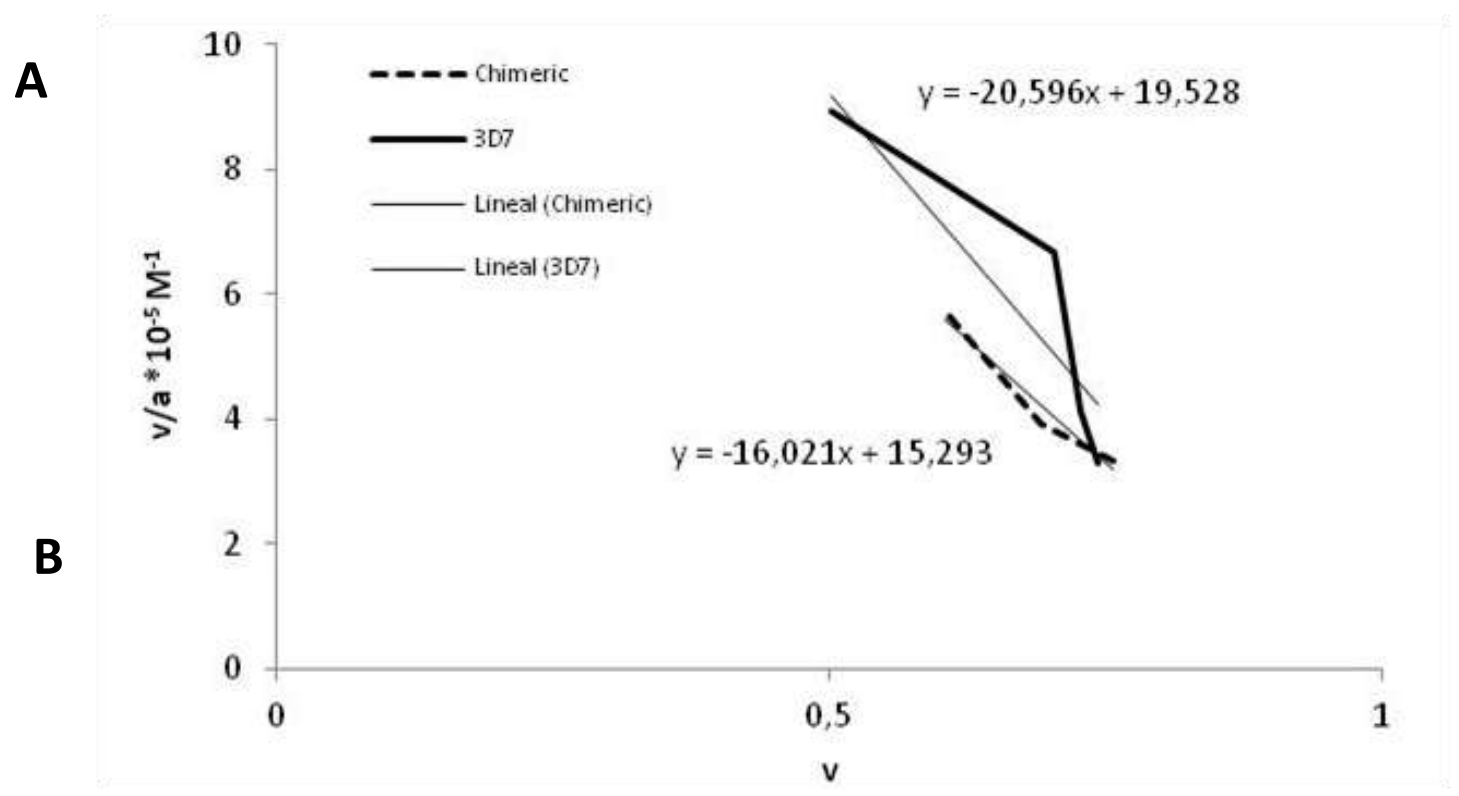

